\title{
THE ROLE OF DISASTER-RESILIENT VILLAGES SUPPORTING TOURISM IN BADUNG DISTRICT
}

\section{PERAN DESA TANGGUH BENCANA MENDUKUNG PARIWISATA DI KABUPATEN BADUNG}

\author{
Made Agus Sugianto ${ }^{1}$ \\ ${ }^{1}$ Badan Penelitian dan Pengembangan Kabupaten Badung \\ agussugianto146@gmail.com
}

\begin{abstract}
Badung Regency is a very famous tourist destination to foreign countries. However, most of these tourist destination areas are located in disaster-prone areas. This study aims to determine the role of disaster-resilient villages in providing security and comfort to tourists visiting tourist objects. This study used a descriptive-analytic method with a desk study design. Disaster Resilient Villages / Kelurahan are villages that have the independent ability to adapt and face potential disaster threats. Currently, there are 31 disaster-resilient villages in Badung Regency, most of which are tourist destination areas. In disaster-resilient coastal areas, the potential for tsunami disasters, highland areas are potentially affected by landslides. The prevention and mitigation efforts that have been carried out by the Badung Regency Government include; build an early warning system, install warning signs, carry out disaster simulations and disseminate information to the public.
\end{abstract}

Keywords: Disaster resilient, tourism, badung regency

\begin{abstract}
Abstrak
Kabupaten Badung merupakan daerah destinasi wisata yang sangat terkenal sampai ke Manca Negara. Namun demikian, sebagian besar daerah destinasi wisata tersebut terletak pada daerah rawan bencana. Penelitian ini bertujuan untuk mengetahui peran desa tangguh bencana dalam memberikan keamanan dan kenyamanan kepada wisatawan yang berkunjung ke obyekobyek wisata. Penelitian ini menggunakan metode deskriptif analitik dengan desain desk study. Desa/Kelurahan Tangguh Bencana adalah desa yang memiliki kemampuan mandiri untuk beradaptasi dan menghadapi potensi ancaman bencana, Saat ini terdapat 31 desa/kelurahan tangguh bencana di Kabupaten Badung yang sebagian besar merupakan daerah destinasi wisata. Pada kawasan pesisir desa tangguh bencana berpotensi terkena bencana tsunami, pada daerah dataran tinggi berpotensi terkena bencana longsor. Upaya pencegahan dan mitigasi yang sudah dilakukan Pemerintah Kabupaten Badung antara lain; membangun sistem peringatan dini, pemasangan rambu-rambu peringatan, melaksanakan simulasi bencana dan sosialisasi kepada masyarakat.
\end{abstract}

Kata kunci : Tangguh bencana, pariwisata, kabupaten badung 


\section{PENDAHULUAN}

Indonesia adalah negara yang rawan bencana dilihat dari aspek geografis, klimatologis dan demografis. Letak geografis Indonesia di antara dua benua dan dua samudera menyebabkan Indonesia mempunyai potensi yang cukup bagus dalam perekonomian sekaligus juga rawan dengan bencana. Secara geologis, Indonesia terletak pada 3 (tiga) lempeng yaitu Lempeng Eurasia, Lempeng IndoAustralia dan Lempeng Pasifik yang membuat Indonesia kaya dengan cadangan mineral sekaligus mempunyai dinamika geologis yang sangat dinamis yang mengakibatkan potensi bencana gempa, tsunami dan gerakan tanah/longsor (BNPB, 2014).

Provinsi Bali adalah salah satu provinsi di Indonesia yang tergolong rawan bencana. Menurut Badan Penanggulangan Bencana Daerah (BPBD) Provinsi Bali, sepanjang tahun 2018 telah terjadi 1.592 bencana di Bali. Bencana yang mendominasi adalah gempa bumi sebanyak 550 kasus skala besar maupun kecil. Berikutnya adalah pohon tumbang 290 kasus, kebakaran 278 kasus, tanah longsor 146 kasus, banjir 117 kasus, dan sisanya seperti puting beliung, bangunan roboh, dan kekeringan. Dari total kasus bencana yang terjadi di Provinsi Bali, sebanyak 250 kasus terjadi di Kabupaten Badung (Rosidin, 2019).

Menurut buku Rencana Kontinjensi Gempa Bumi dan Tsunami, potensi bencana yang ada di Kabupaten Badung meliputi gempa bumi, tsunami, angin puting beliung serta tanah longsor. Sejarah bencana yang pernah terjadi di kabupaten Badung merupakan rangkuman historis seluruh kejadian bencana meliputi bencana alam, non alam dan sosial yang dibagi ke dalam kelompok bencana geologi, hidrometeorologi, biologi dan konflik sosial. Disamping sebagai daerah rawan bencana, Kabupaten Badung adalah "surga" bagi ribuan wisatawan yang datang berkunjung ke kabupaten ini setiap tahun. Selama dasawarsa terakhir, ekonomi Kabupaten Badung telah menjadi sangat bergantung pada industri pariwisata. Banyak pembangunan utama di Bali, khususnya yang berkaitan dengan pariwisata berlokasi tepat di pesisir selatan yang menghadap
Samudera India. Apabila terjadi bencana, wisatawan dan masyarakat yang ada di kawasan rawan bencana akan menjadi korban, selain itu bencana akan menghancurkan hasil-hasil pembangunan yang sudah diperoleh selama ini (BPBD Kab.Badung, 2013).

Perlindungan wisatawan dan masyarakat dari ancaman bencana haruslah dilakukan oleh semua pihak, seperti pemerintah, pekerja sosial, masyarakat, maupun stakeholders lain yang terkait. Hal yang paling mendesak adalah menumbuhkan kesadaran dan kemampuan masyarakat untuk melindungi diri sendiri dari ancaman dan resiko bencana. Menurut Herianto, dkk (2014), pemberdayaan masyarakat dalam mitigasi bencana dilaksanakan dengan cara pembentukan Community-based disaster di masyarakat. Penciptaan community-based disaster dengan kata lain membangun ketahanan masyarakat dalam menghadapi bencana pada sebelum, saat terjadi bencana, maupun pasca bencana. Salah satu strategi yang digunakan untuk mewujudkan ini adalah melalui pembentukan desa-desa atau kelurahankelurahan yang tangguh terhadap bencana.

Desa/Kelurahan Tangguh Bencana (Destana) adalah desa yang memiliki kemampuan mandiri untuk beradaptasi dan menghadapi potensi ancaman bencana, serta memulihkan diri dengan segera dari dampak bencana yang merugikan. Pembentukan destana merupakan salah satu upaya pengurangan risiko bencana berbasis masyarakat. $\mathrm{Di}$ dalam desa/kelurahan tangguh bencana, masyarakat terlibat aktif dalam mengkaji, menganalisis, menangani, memantau, mengevaluasi dan mengurangi risiko-risiko bencana yang ada di wilayah mereka, terutama dengan memanfaatkan sumber daya lokal demi menjamin keberkelanjutan (BNPB, 2012).

Melalui pembentukan desa/kelurahan tangguh bencana diharapkan upaya pencegahan dan mitigasi bencana pada obyek-obyek wisata di wilayah desa/kelurahan rawan bencana dapat berjalan secara terpadu, efektif dan efisien, sehingga dapat menciptakan rasa aman dan nyaman pada masyarakat dan 
wisatawan yang berkunjung ke obyek wisata tersebut.

\section{METODE PENELITIAN}

Penelitian ini adalah penelitian deskriptif analitik dengan desain Desk Study, dimana penelitian ini menganalisis data menggunakan data sekunder yang ada. Penelitian ini dilaksanakan di Kabupaten Badung selama dua bulan yaitu dari bulan Juni sampai dengan Juli 2019. Data penelitian ini bersumber dari laporan program penanggulangan bencana dan program pengembangan desa wisata di Kabupaten Badung

\section{HASIL DAN PEMBAHASAN}

Kabupaten Badung memiliki banyak destinasi wisata yang sangat terkenal sampai ke manca negara. Berdasarkan data Profil Dinas Pariwisata Kabupaten Badung Tahun 2019, Kurang lebih terdapat 99 obyek wisata alam di Kabupaten Badung yang meliputi pantai, lembah, sungai maupun persawahan. Beberapa obyek wisata alam yang cukup terkenal antara lain; pantai Kuta, pantai Pendawa, jembatan Tukad Bangkung. Selain memiliki objek wisata alam, Kabupaten Badung juga terkenal sebagai destinasi wisata konvensi dan tempat dilaksanakan event internasional seperti IMF Side Event, World or Music Art and Dance (WOMAD) dan Badung International Night Run.

Jumlah obyek wisata yang begitu banyak dan adanya kegiatan promosi wisata menyebabkan terjadinya peningkatan kunjungan wisata ke Kabupaten Badung. Data Profil Dinas Pariwisata Kabupaten Badung menunjukan adanya peningkatan kunjungan wisatawan setiap tahun ke Kabupaten Badung seperti terlihat pada Gambar 1

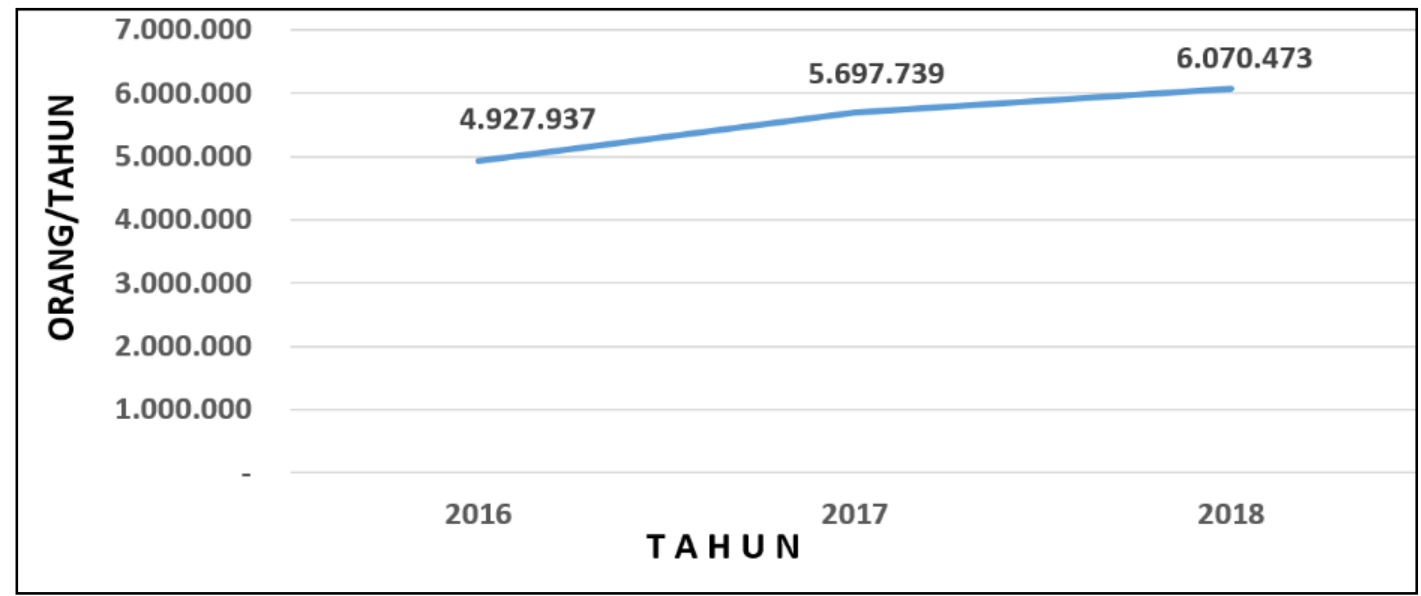

Sumber: diolah dari data Profil Dinas Pariwisata Kab Badung (2019)

Gambar 1. Jumlah kunjungan wisatawan di Kabupaten Badung

Peningkatan jumlah kunjungan wisatawan ini tentunya menuntut Pemerintah Kabupaten Badung untuk meningkatkan pelayanan publik dengan cara memberi rasa aman dan nyaman kepada wisatawan. Bedasarkan data Badan Penanggulangan Bencana Daerah (BPBD)
Kabupaten Badung, beberapa obyek wisata yang ada di Kabupaten Badung terletak di daerah rawan bencana khususnya bencana tanah longsor dan tsunami. Peta daerah risiko bencana dapat dilihat pada gambar 2 . 


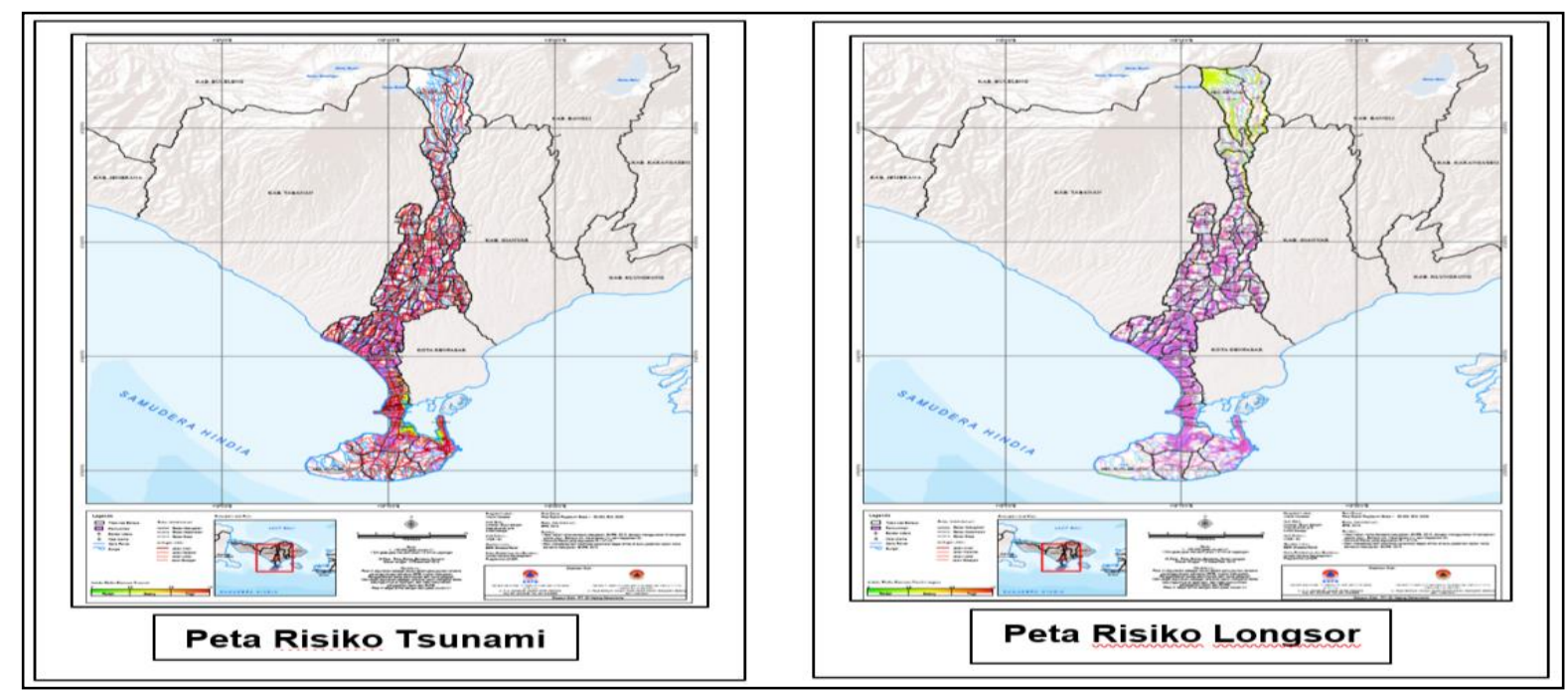

Sumber: Badan Nasional Penanggulanga Bencana (2019)

Gambar 2. Peta Daerah Risiko Tsunami dan Longsor di Kabupaten Badung

Mengingat sebagian besar destinasi wisata di Kabupaten Badung adalah daerah rawan bencana, maka BPBD Kabupaten Badung melakukan upaya pencegahan dan mitigasi bencana dengan cara memberdayakan masyarakat dibidang kebencanaan melalui pembentukan desa tangguh bencana (destana). Dengan terbentuknya destana maka diharapkan tercipta sinergitas antara pemerintah daerah dengan masyarakat dalam pencegahan dan mitigasi bencana. Berdasarkan profil BPBD Kabupaten Badung, jumlah destana di Kabupaten Badung setiap tahun menunjukan peningkatan seperti terlihat pada Gambar 3.

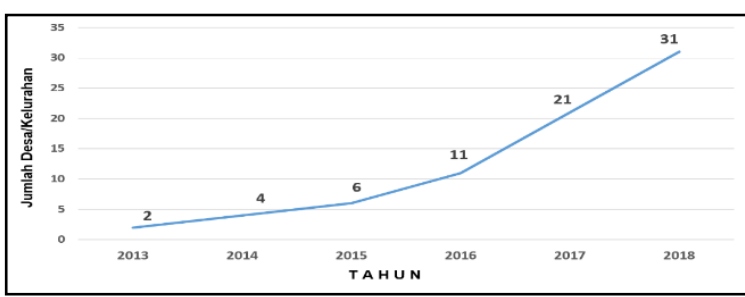

Sumber: diolah dari Data BPBD Kabupaten Badung (2019)

Gambar 3. Jumlah Desa/Kelurahan Tangguh Bencana di Kabupaten Badung

31 desa/kelurahan yang dibentuk menjadi destana tersebar pada 6 kecamatan di wilayah Kabupaten Badung seperti terlihat pada gambar 4.

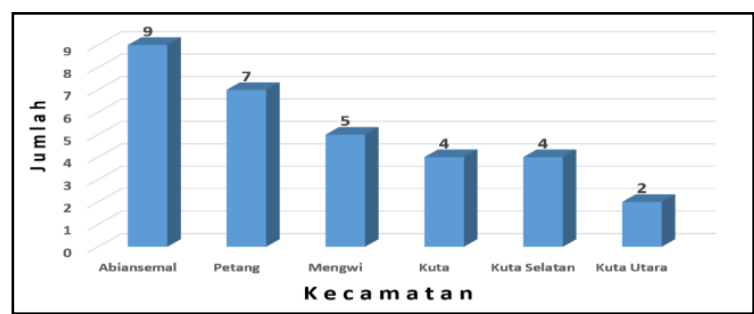

Sumber: diolah dari Data BPBD Kabupaten Badung (2019)

Gambar 4. Jumlah Desa/Kelurahan Tangguh Bencana Per Kecamatan

Bencana alam yang menjadi prioritas untuk dilakukan pencegahan dan mitigasi pada 31 desa/kelurahan destana di Kabupaten Badung dapat dilihat pada gambar 4.

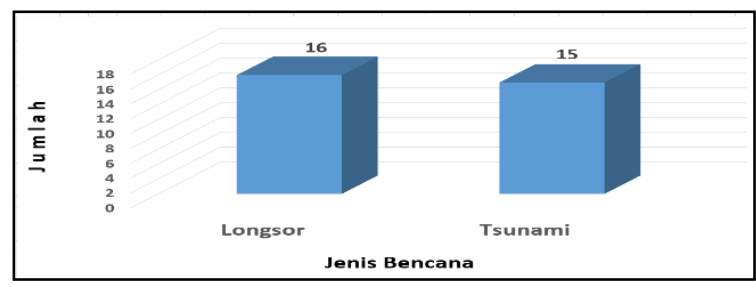

Sumber: diolah dari Data BPBD Kabupaten Badung (2019)

Gambar 4. Jenis Bencana Desa/Kel Tangguh Bencana di Kabupaten Badung

Berdasarkan hasil analisa kajian risiko Kabupaten Badung, didapatkan total luasan wilayah yang terdampak bahaya banjir seluas $5,56 \%(40.730 \mathrm{Ha})$ dari luas wilayah Kabupaten Badung. Dengan demikian maka didapatkan tingkat bahaya tanah 
longsor di Kabupaten Badung adalah tinggi. Berdasarkan hasil pengkajian risiko bencana longsor di Kabupaten Badung, didapatkan kelas indeks penduduk terpapar adalah rendah, dan kelas indeks kerugian tinggi. Dengan demikian dapat disimpulkan bahwa tingkat kerentanan di Kabupaten Badung adalah sedang (BNPB, 2019).

Kejadian bencana tanah longsor dilaporkan terjadi pada bulan Pebruari 2017 di desa Pelaga dan desa Belok Sidan Kecamatan Petang. Meskipun tidak ada korban jiwa, namun kejadian ini mengakibatkan kemacetan lalu lintas karena tanah yang longsor menutupi badan jalan. Pada waktu yang bersamaan, terjadi juga tanah longsor di desa Petang yang mengakibatkan bangunan sekolah jebol (Suryani, 2017). Pada bulan Desember 2018 kembali terjadi bencana tanah longsor di 3 (tiga) kecamatan yaitu Kecamatan Petang (Desa Pangsan), Kecamatan Mengwi (Desa Munggu dan Desa Buduk), Kecamatan Abiansemal (Desa Taman dan Desa Ayunan) dan kelurahan Kerobokan Kaja Kecamatan Kuta Utara. Beberapa desa seperti desa Pelaga, desa Belok Sidan, desa Petang, desa Pangsan dan desa Munggu merupakan desa wisata yang ada di Kabupaten Badung (BPBD Kab. Badung, 2019).

Hasil penelitian Murdiyanto (2015) di Kota Jayapura menyimpulkan bahwa terjadinya erosi disebabkan karena terjadinya penggundulan hutan, penyempitan lebar sungai karena dibangunnya permukiman penduduk dan bangunan tempat usaha di bantaran sungai, serta pembuangan sampah yang dilakukan masyarakat tidak pada tempatnya. Upaya yang dilakukan untuk penanggulangan bencana erosi (tanah longsor) adalah dengan memberi penyuluhan dan penyadaran kepada masyarakat tentang manfaat penghijauan. Terkait dengan penelitian tersebut, maka pada bulan Juni 2019 kelompok siaga bencana desa Pelaga Kecamatan Petang bersama dengan Dinas Lingkungan Hidup dan Kebersihan Kabupaten Badung, Camat Petang dan media Bali Post melaksanakan kegiatan penanaman pohon di areal Tukad
Bangkung. Pada tahun yang sama (2019), kelompok siaga bencana desa Getasan bersama BPBD Kabupaten Badung juga mengadakan sosialisasi dan simulasi bencana yang melibatkan semua elemen masyarakat. Untuk meningkatkan kewaspadaan wisatawan dan masyarakat setempat, kelompok siaga bencana di Kecamatan Petang, Abiansemal dan Mengwi bersama BPBD Kabupaten Badung melakukan pemasangan rambu-rambu pada daerah yang rawan longsor. (BPBD Kab. Badung, 2019).

Berbeda dengan desa/kelurahan di wilayah badung tengah dan badung utara, desa/kelurahan yang terletak di sepanjang pesisir selatan Kabupaten Badung justru berpotensi diterjang tsunami karena berada pada zona tumbukan tektonik yang merupakan sumber gempa bumi. Hal yang menarik, pada kawasan ini terdapat banyak obyek wisata terkenal seperti pantai Tanjung Benoa, kawasan BTDC Nusa Dua, pantai Pandawa, pantai Kuta dan lain-lain yang banyak dikunjungi oleh wisatawan domestik maupun manca negara. Oleh karena itu, desa tangguh bencana memiliki peran yang sangat penting dan strategis dalam memberikan sosialisasi dan peringatan dini kepada wisatawan berkunjung ke obyek-obyek wisata tersebut.

Tsunami merupakan salah satu jenis bencana alam yang berkaitan dengan gelombang lautan yang sangat besar dan menerjang daratan. Tsunami berasal dari bahasa Jepang, Tsu yang berarti pelabuhan dan Nami yang berarti gelombang. Meskipun kejadian tsunami di Kabupaten Badung terjadi hanya satu kali yaitu pada bulan Agustus 1977 (mengakibatkan 1 unit rumah rusak berat), namun hasil pengkajian risiko bencana Kabupaten Badung menyimpulkan bahwa indeks penduduk terpapar adalah tinggi dan indeks kerugian juga tinggi. Dengan demikian dapat disimpulkan bahwa tingkat kerentanan masyarakat badung terhadap tsunami adalah tinggi (BPBD Kab.Badung, 2014). Luasan daerah potensi tsunami di Kabupaten Badung terlihat pada Tabel 1. 
Tabel 1. Luasan daerah potensi tsunami di Kabupaten Badung

\begin{tabular}{|c|c|c|c|c|}
\hline \multirow{2}{*}{ No } & \multirow{2}{*}{ Kecamatan } & \multicolumn{2}{|c|}{ Potensi (ha) } & \multirow{2}{*}{$\begin{array}{c}\text { Jumlah } \\
\text { (ha) }\end{array}$} \\
\hline & & Sedang & Tinggi & \\
\hline 1 & Mengwi & 66,96 & 40,95 & 107,91 \\
\hline 2 & Kuta Utara & 358,56 & 119,97 & 478,53 \\
\hline 3 & Kuta & 251,91 & 1728,45 & 1980,36 \\
\hline 4 & $\begin{array}{l}\text { Kuta } \\
\text { Selatan }\end{array}$ & 458,82 & 825,75 & 1284,57 \\
\hline
\end{tabular}

Sumber: BPBD Kabupaten Badung (2013)

Pada tahun 2006 Badan Meteorologi, Klimatologi dan Geofisika (BMKG) membangun lima tower Tsunami Early Warning System (TEWS) yang berlokasi di kelurahan Kedonganan, kelurahan Tanjung Benoa, kelurahan Seminyak, kawasan BTDC Nusa Dua dan Kelurahan Kuta. Kelima kawasan ini dipilih karena merupakan pusat destinasi wisata di Kabupaten Badung.

Menurut BNPB (2014) dalam buku Pedoman Kesiapsiagaan Menghadapi Gempa Bumi Dan Tsunami Berbasis Masyarakat menyebutkan bahwa salah satu tindakan membangun kesiapsiagaan masyarakat menghadapi gempabumi tsunami untuk parameter sistem peringatan bencana adalah dengan kampanye pengurangan risiko bencana melalui berbagai media informasi yang tersedia. Terkait dengan hal tersebut, BPBD Kabupaten Badung bersama kelompok siaga bencana desa/kelurahan di Kecamatan Kuta dan Kecamatan Kuta Selatan memasang rambu-rambu dan peta evakuasi sebagai langkah antisipasi terjadi bencana tsunami. Bila terjadi ancaman tsunami, maka masyarakat harus segera melakukan menjauhi pantai atau langkah evakuasi vertikal dengan mencari tempattempat tinggi seperti hotel atau rumah minimal berlantai tiga. Untuk wilayah Badung Selatan, BPBD Kabupaten Badung sudah membuat Kesepakatan Bersama (MoU) dengan sejumlah hotel, apabila terjadi bencana tsunami, maka hotel tersebut wajib memberikan tempat berlindung kepada masyarakat (BPBD Kab.Badung, 2019).

Dalam rangka meningkatkan kesiapsiagaan bencana tsunami, pada bulan Agustus 2017 dilaksanakan sosialisasi dan simulasi gempa bumi dan tsunami di kelurahan Tanjung Benoa Kecamatan Kuta Selatan. Simulasi ini melibatkan sekitar 400 siswa sekolah dasar, masyarakat, dan karyawan hotel di wilayah tersebut. Selanjutnya pada bulan April 2019 BPBD Provinsi Bali bekerjasama dengan BPBD Kabupaten Badung dan kelompok siaga bencana kelurahan Benoa melaksanakan Gladi Simulasi Gempa Bumi dan Tsunami yang dilakukan dibeberapa hotel di Kawasan ITDC Bali. Untuk menjamin keamanan dan kenyamanan wisatawan, BPBD Provinsi Bali telah mengeluarkan sebanyak 14 sertifikat kepada hotel-hotel yang dinyatakan memiliki kesiapsiagaan terhadap bencana tsunami. Hotel-hotel ini berada di kecamatan Kuta dan Kecamatan Kuta Selatan. Apabila sudah mengantongi sertifikat, maka hotel tersebut dianggap kesiapsiagaan dari ancaman bencana alam termasuk tsunami (BPBD Kab.Badung 2019).

Peran desa/kelurahan tangguh bencana dalam melakukan pencegahan dan mitigasi bencana pada obyek-obyek wisata memang belum optimal, namun upaya yang sudah dilakukan selama ini patut mendapat apresiasi mengingat upaya penanggulangan bencana merupakan masalah yang cukup kompleks. Oleh karena itu diperlukan komitmen dan dukungan berbagai pihak untuk meningkatkan kesiapsiagaan terhadap risiko bencana agar korban jiwa dan kerugian harta benda dapat diminimalisir.

\section{KESIMPULAN}

Saat ini sudah dibentuk sebanyak 31 desa/kelurahan tangguh bencana di Kabupaten Badung yang sebagian besar merupakan daerah destinasi wisata. 
Pembentukan desa/kelurahan tangguh bencana dimaksudkan agar masyarakat bisa terlibat aktif dalam mengkaji, menganalisis, menangani, memantau, mengevaluasi dan mengurangi risiko-risiko bencana yang ada di wilayah mereka. Desa/kelurahan tangguh bencana yang berada pada kawasan pesisir selatan Kabupaten Badung berpotensi terkena bencana tsunami, sedangkan pada daerah badung tengah dan badung utara berpotensi terkena bencana longsor. Untuk mengurangi korban jiwa baik pada masyarakat maupus wisatawan, destana sudah melakukan berbagai upaya pencegahan dan mitigasi bencana dengan cara melakukan penghijauan, membangun sistem peringatan dini, pemasangan ramburambu peringatan, melakukan sosialisasi dan simulasi bencana.

\section{DAFTAR PUSTAKA}

BNPB, 2014, Pedoman Kesiapsiagaan Menghadapi Gempabumi Dan Tsunami Berbasis Masyarakat.

BNPB, 2019, Peta Daerah Risiko Bencana Tsunami dan Longsor di Kab.Badung. (http://inarisk.bnpb.go.id/. Diakses pada tanggal 30 Agustus 2019 pada jam 08.00).

BNPB Kab. Badung, 2014, Dokumen Kajian Risiko Bencana Kabupaten Badung 2014-2018.

BPBD Kab.Badung, 2013, Rencana Kontinjensi Bencana Gempa Bumi danTsunami.

BPBD Kab.Badung, 2014, Rencana Penanggulangan Bencana (RPB) Kabupaten Badung 2014-2018.

BPBD Kab Badung, 2019. Profil BPBD Kab Badung Tahun 2019.Agus, F., A.Ng.Ginting, dan M. van Noordwidjk. 2002. Pilihan Teknologi Agroforestri/ Konservasi Tanah Untuk Areal Pertanian Berbasis Kopi di Sumberjaya, Lampung Barat. International Centre for Research in Agroforestry, Bogor.

Dinas Pariwisata Kab Badung, 2019, Profil Dinas Pariwisata Kab Badung Tahun 2018.

Murdiyanto, Tri Gutomo, 2015, Bencana Alam Banjir dan Tanah Longsor dan
Upaya Masyarakat dalam

Penanggulangan. Balai Besar Penelitian dan Pengembangan Pelayanan Kesejahteraan Sosial (B2P3KS) Kementerian Sosial RI Yogyakarta. Jurnal PKS Vol 14 No 4 Desember 2015; 437 - 452. (Downloads/1338-3908-1-

SM\%20(1).pdf. Diakses pada tanggal 2 September 2019 pukul 08.00)

Peraturan Kepala Badan Nasional Penanggulangan Bencana Nomor 1 Tahun 2012 Tentang Pedoman Umum Desa/Kelurahan Tangguh Bencana.

Rosidin, Imam, 2019, 550 Kasus Gempa Bumi Pernah Terjadi di Bali Sepanjang 2018. (https://bali.idntimes.com/news/bali/i mamrosidin/kasus-bencana-yangpernah-terjadi-di-bali-sepanjang/full. Diakses pada tanggal 28 Agustus 2019 pada jam 09.00).

Suriyani, Luh De 2017, Longsor di Sejumlah Kabupaten di Bali, 12 Meninggal. (https://www. mongabay.co.id/2017/02/11/longsordi-sejumlah-kabupaten-di-bali-12meninggal/. Diakses pada tanggal 1 September 2019 pada pukul 08.00). 